\title{
Article \\ Is There Pathological Uniformity between the Periphery and Center of a Gastrointestinal Stromal Tumor?
}

\author{
Seong Ji Choi ${ }^{1,+} \mathbb{D}$, Kwan Hong Lee ${ }^{1,+}$, Chan Kyoo Yoo ${ }^{1}$, Jai Hoon Yoon ${ }^{1}$, Ki Seok Jang ${ }^{2}$, Youn Jeong Kim ${ }^{3, * \mathbb{D}}$ \\ and Hang Lak Lee ${ }^{1, *}$ \\ 1 Department of Gastroenterology, Hanyang University Hospital, Seoul 04763, Korea; \\ drcoolandy@gmail.com (S.J.C.); kwansover@naver.com (K.H.L.); camebulmyul@gmail.com (C.K.Y.); \\ jaihoonyoon@hanyang.ac.kr (J.H.Y.) \\ 2 Department of Pathology, College of Medicine, Hanyang University, Seoul 04763, Korea; \\ medartisan@hanyang.ac.kr \\ 3 Department of Internal Medicine, College of Medicine, The Catholic University of Korea, Incheon ST. Mary's \\ Hospital, Incheon 21431, Korea \\ * Correspondence: muze1004@catholic.ac.kr (Y.J.K.); alwayshang@hanyang.ac.kr (H.L.L.); \\ Tel.: +82-32-280-5018 (Y.J.K.); +82-02-2290-8354 (H.L.L.) \\ + Contributed equally to this work as first author.
}

check for updates

Citation: Choi, S.J.; Lee, K.H.; Yoo, C.K.; Yoon, J.H.; Jang, K.S.; Kim, Y.J.; Lee, H.L. Is There Pathological Uniformity between the Periphery and Center of a Gastrointestinal Stromal Tumor? J. Clin. Med. 2021, 10, 687. https:// doi.org/10.3390/jcm10040687

Academic Editor: Bruno Annibale

Received: 20 January 2021

Accepted: 8 February 2021

Published: 10 February 2021

Publisher's Note: MDPI stays neutral with regard to jurisdictional claims in published maps and institutional affiliations.

Copyright: (c) 2021 by the authors. Licensee MDPI, Basel, Switzerland. This article is an open access article distributed under the terms and conditions of the Creative Commons Attribution (CC BY) license (https:// creativecommons.org/licenses/by/ $4.0 /)$.

\begin{abstract}
Background: Gastrointestinal stromal tumors (GISTs) are mesenchymal tumors and have some malignant potential. Mitotic count is important for predicting the malignant potential of GISTs. Proper treatment of GISTs requires accurate pathological diagnosis. In general, endoscopic ultrasound-guided fine-needle aspiration and deep biopsy are used for pathological diagnosis of GIST before making decisions about surgery. This study sought to evaluate the pathological uniformity of gastric GISTs for mitotic index of the center and periphery of the GIST. Methods: We retrospectively reviewed the data of 37 gastric GIST patients who underwent wedge resection at Hanyang University Hospital. We used Armed Forces Institute of Pathology criteria to classify gastric GISTs. To determine the pathological uniformity of gastric GISTs, we compared GIST risk stratification between the center and periphery of GISTs. Results: The mean size of GISTs was $3.56 \pm 2.10 \mathrm{~cm}$. Three lesions were located in the antrum, 11 in the fundus, 9 in the cardia, and 14 in the body. The mean age of patients was $58.65 \pm 9.44$ years; 18 patients were male and 19 were female. Thirty-five patients $(94.6 \%)$ showed the same level of risk stratification between the center and periphery of gastric GISTs, while two patients $(5.4 \%)$ presented different levels of risk between the two sites. No significant difference in mitotic count was observed between the two sites (kappa value $=0.863 ; p=0.001$ ). Conclusions: Mitotic index category (either more than five mitoses per high-power field or five or fewer mitoses per high-power field) of GISTs showed good concurrence between the center and periphery.
\end{abstract}

Keywords: gastric gastrointestinal stromal tumors; mitotic count; pathological uniformity

\section{Introduction}

Gastrointestinal stromal tumors (GISTs) are well-understood mesenchymal tumors that originate from the interstitial cells of Cajal known as intestinal pacemakers [1]. Because of improvements in diagnostic technique and increase in routine health care examinations, the incidence of GISTs is increasing in several countries [2-4]. GISTs may be asymptomatic and found incidentally; however, they are currently regarded as potentially malignant tumors, with about $10 \%$ to $30 \%$ progressing definitively to malignancy [5]. Risk stratification in patients with GISTs is important to determine treatment, follow-up strategies, and prognosis. There have been some prognostication systems introduced to predict malignant potential such as metastasis or recurrence, with several studies reporting that tumor size, mitotic index, primary tumor site, and tumor rupture are associated with prognosis in patients with GISTs [6-9]. According to the National Institutes of Health consensus criteria published in 2002, the most important prognostic factors of GISTs are 
mitotic index and tumor size [9]. Elsewhere, Armed Forces Institute of Pathology (AFIP) criteria considered tumor location to be a prognostic factor and, in cases of gastric GISTs, a tumor size of $10 \mathrm{~cm}$ or less and $\leq 5$ mitoses per 50 high-power fields (HPFs) impart a low risk for metastasis, whereas those with $>5$ per 50 HPFs and tumors measuring greater than $5 \mathrm{~cm}$ in diameter have a high risk for metastasis [10]. Mitotic rate represents tumor cell proliferation; therefore, mitotic index has been suggested to be one of the most important factors to predict the behavior of cells in patients with GISTs [11]. However, mitosis identification must be conducted carefully because it can be subjective according to pathologist or measurement site, and it remains unknown where is the best place to measure mitotic index. In addition, endoscopic approaches such as endoscopic ultrasound (EUS)-guided fine-needle aspiration (FNA) or deep biopsy, which are traditionally considered the most established tissue sampling methods for gastric GISTs, would be confined to assessing peripheral lesions with small tissue volume because of their difficulty in approaching the tumor. It is not clear whether or not the preoperative pathologic diagnosis of gastric GISTs using endoscopy would accurately represent the whole mass. To our knowledge, no recent studies have commented on differences in mitotic index between the periphery and center of the tumor in patients with GISTs. When diagnosing GISTs of the stomach, it is important to know whether the biopsy findings can accurately diagnose the pathological findings of the entire GIST when performing histological confirmation through ultrasound or deep biopsy. Therefore, this study sought to confirm the pathological uniformity of the number of mitoses between the periphery and the center of the lesion in gastric GISTs.

\section{Methods}

\subsection{Patients}

A total of 37 patients who underwent curative surgical resection for gastric GISTs at Hanyang University Seoul Hospital between January 2008 and December 2014 was included. We reviewed the pathological and clinical data retrospectively. This study was approved by the Institutional Review Board of Hanyang University Seoul Hospital (no. 2015-02-004-001).

\subsection{Surgical Resection}

Surgical resection was performed in patients with gastric GISTs measuring larger than $2 \mathrm{~cm}$ with consideration of increasing tumor size; symptoms; physician opinion; patient preference; or EUS features indicating high risk of malignancy such as large size, irregular border, heterogeneous echogenicity, cystic spaces, or hyperechoic foci. Of 37 patients with gastric GISTs, 35 (94.6\%) were treated by wedge resection, one underwent antrectomy with Billroth anastomosis, and one underwent total gastrectomy. A single experienced surgeon who worked at Hanyang University Hospital, Hanyang University College of Medicine performed all surgeries.

\subsection{Pathological Diagnosis of Gastric GISTs}

All slides were stained by hematoxylin and eosin to identify mitotic index. We counted mitotic figures by visual inspection with a $400 \times$ magnification. Pathological diagnosis of gastric GISTs was based on histopathology (i.e., epithelioid, spindle cell, mixed) and immunohistochemical analysis using CD117 (c-kit), CD34, S100, desmin, and smooth muscle actin antibodies.

\subsection{Risk Stratification}

The risk assessment of the tumors was conducted by applying the criteria of the AFIP. Patients were divided into four prognostic groups (very low, low, intermediate, and high risk) by tumor size, location, and mitotic rate to evaluate the likelihood of gastric GIST malignant behavior (Table 1) [8,10]. All slides were re-reviewed by a single pathologist specializing in gastrointestinal pathology. In clinically reported general pathology reports (primary reports), mitosis was counted in the most active cellular area of the pathologic 
specimen. GIST centers were defined as a part of the tumor starting at $5 \mathrm{~mm}$ from the surface of the tumor (Figure 1). We compared the level of risk stratification between the center and periphery of GIST masses. Mitotic index was counted under $50 \mathrm{HPFs}$ and at three different sites within the tumor (Figures 1 and 2).

Table 1. Risk stratification of gastric gastrointestinal stromal tumors (GISTs) (risk for progressive disease) ${ }^{\dagger}$.

\begin{tabular}{ccc}
\hline Risk of Progression (\%) & Mitotic Index (High-Power Field) & Tumor Size (cm) \\
\hline None $(0 \%)$ & $\leq 5 / 50$ & $\leq 2$ \\
None (0\%, small cases) & $>5 / 50$ & $\leq 2$ \\
Very low (1.9\%) & $\leq 5 / 50$ & $>2, \leq 5$ \\
Low $(3.6 \%)$ & $\leq 5 / 50$ & $>5, \leq 10$ \\
Moderate $(12 \%)$ & $\leq 5 / 50$ & $>10$ \\
$(16 \%)$ & $>5 / 50$ & $>2, \leq 5$ \\
High $(55 \%)$ & $>5 / 50$ & $>5, \leq 10$ \\
$(86 \%)$ & $>5 / 50$ & $>10$ \\
\hline
\end{tabular}

${ }^{\dagger}$ modified from Miettinen et al [1]; ${ }^{* *}$ Small number of cases.

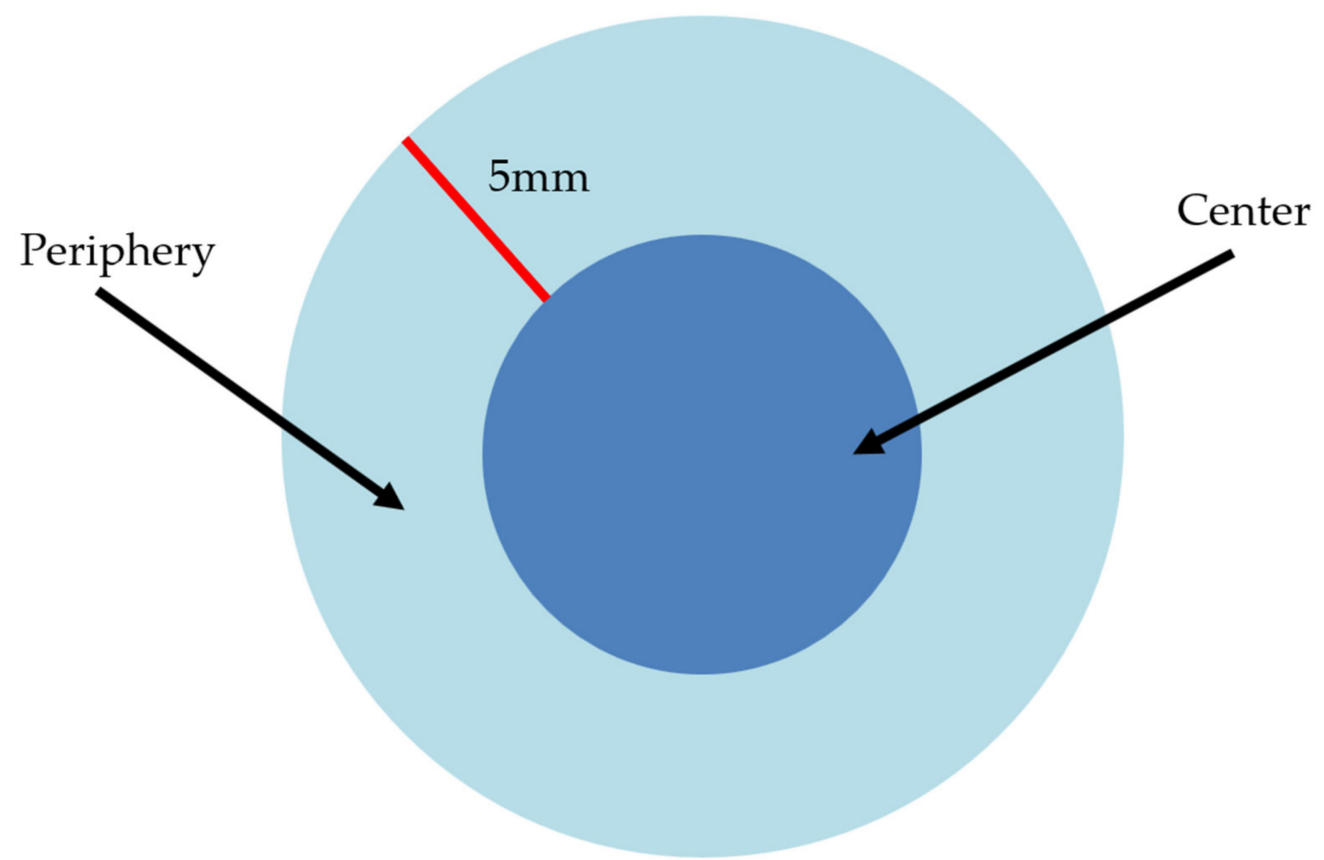

Figure 1. Schematic definitions of the center and periphery of a gastric gastrointestinal stromal tumors (GISTs) during pathological review.

\subsection{Statistical Analysis}

Continuous variables were expressed as mean \pm standard deviation (SD), and categorical variables were expressed as frequency (\%). Categorical data were analyzed using the Chi-square test with kappa values to compare tumor size and mitotic index between the periphery and center. $P$-values $<0.05$ were considered statistically significant. All analyses used the Statistical Package for the Social Sciences version 18.0 (IBM Corp., Armonk, NY, USA). 


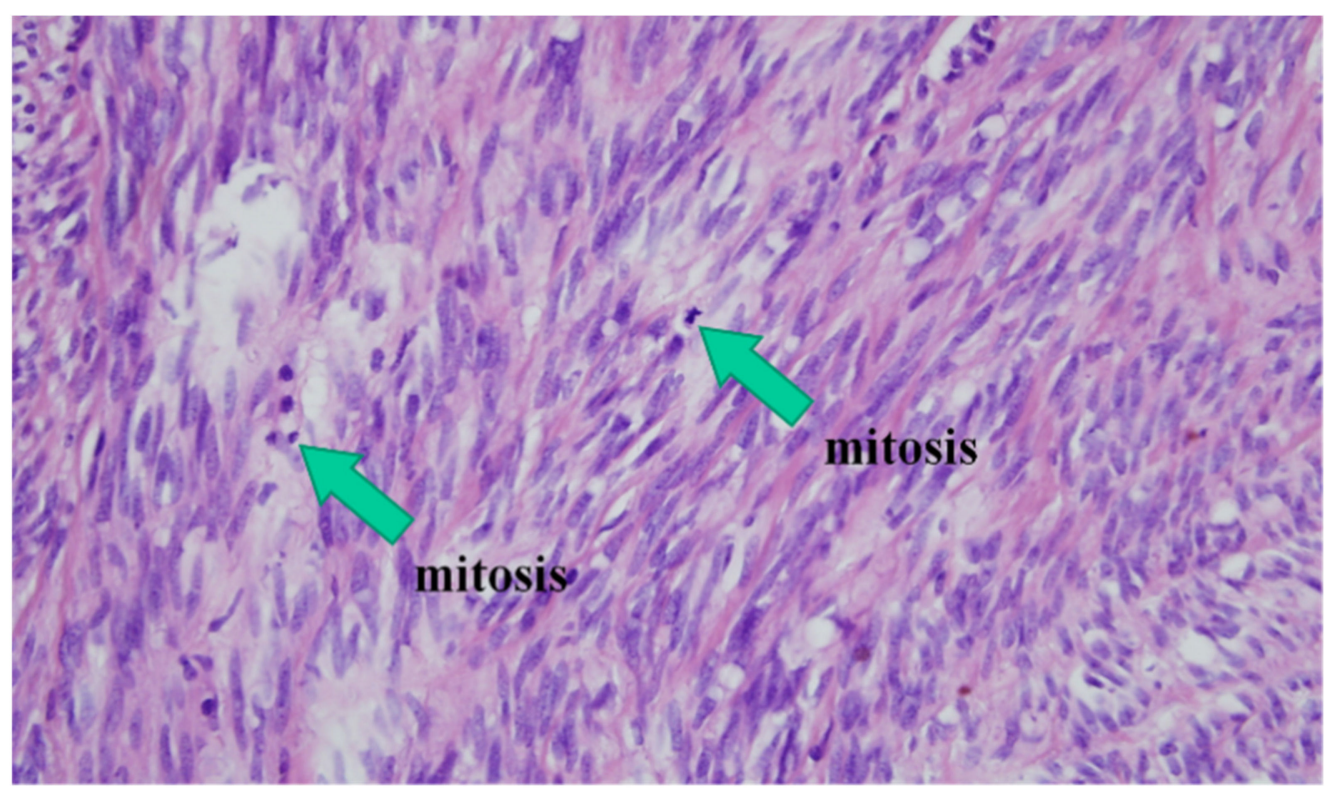

Figure 2. Mitosis in pathological findings. hematoxylin and eosin, original magnification, $400 \times$.

\section{Results}

\subsection{Clinical Features of Gastric GISTs}

Table 2 presents the baseline characteristics and endoscopic findings of 37 gastric GIST patients with a 1:1.06 male-to-female ratio and a mean age of $58.65 \pm 9.44$ years (range: $40-76$ years). The mean tumor size was $3.56 \pm 2.10$ (range: $2.0-11.5) \mathrm{cm}$, and $32(86.5 \%)$ measured between 2 and $5 \mathrm{~cm}$. Of these, 27 cases (72.9\%) were found incidentally on endoscopy during a health care examination and, among 10 symptomatic cases, nausea and anorexia $(n=5)$ were the most common symptoms, followed by abdominal discomfort $(n=4)$ and gastrointestinal bleeding $(n=1)$. Gastric body was the most common involved site $(n=14 ; 37.8 \%)$, followed by fundus $(n=11 ; 29.7 \%)$, cardia $(n=9 ; 24.3 \%)$, and antrum $(n=3 ; 8.1 \%)$. Endoscopic ultrasonography revealed findings of $100 \%$ hypoechoic lesions and $64.9 \%(n=24)$ with a heterogeneous echo pattern. Positive CD34, desmin, SMA, and S-100 expression was detected in $94.6 \%, 2.7 \%, 10.8 \%$, and $5.4 \%$ of the GISTs, respectively. One patient experienced recurrence.

Table 2. Baseline characteristics of enrolled patients.

\begin{tabular}{cc}
\hline & Gastric GISTs $(n=37)$ \\
\hline Age, years & $58.65 \pm 9.44(40-76)$ \\
Sex (M/F) & $18(48.6 \%) / 19(51.4 \%)$ \\
Weight (kg) & $66.62 \pm 10.08(46-86)$ \\
Height (meters) & $1.62 \pm 0.92(1.44-1.88)$ \\
BMI (kg/m ( $\left.^{2}\right)$ & $25.30 \pm 2.92(19.40-30.86)$ \\
Symptomatic GISTs, $n(\%)$ & $10(27 \%)$ \\
Abdominal pain & $4(10.8 \%)$ \\
Hematemesis & $1(2.7 \%)$ \\
Nausea, anorexia & $5(13.5 \%)$ \\
Incidental GISTs, $n(\%)$ & $27(73 \%)$ \\
DM, $n(\%)$ & $10(27 \%)$ \\
Hypertension, $n(\%)$ & $19(51.4 \%)$ \\
Hepatitis, $n(\%)$ & $2(2.7 \%)$ \\
Malignancy, $n(\%)$ & $2(5.4 \%)$ \\
Size $(\mathrm{cm})$ & $3.56 \pm 2.10(2.0-11.5)$ \\
Location, $n(\%)$ & $3(8.1 \%)$ \\
Antrum &
\end{tabular}


Table 2. Cont.

\begin{tabular}{cc}
\hline & Gastric GISTs $(\boldsymbol{n}=\mathbf{3 7 )}$ \\
\hline Body & $14(37.8 \%)$ \\
Fundus & $11(29.7 \%)$ \\
Cardia & $9(24.3 \%)$ \\
EUS findings & \\
Echogenicity, $n(\%)$ & \\
Hypoechoic/hyperechoic & $37(100 \%) / 0(0 \%)$ \\
Homogeneity, $n(\%)$ & \\
Homogenous & $13(35.1 \%)$ \\
Heterogenous & $24(64.9 \%)$ \\
Cystic change & \\
Negative/positive & $20(54.1 \%) / 17(45.9 \%)$ \\
Ulcer of gastric mucosa & $6(16.2 \%)$ \\
Immunohistochemistry, $n(\%)$ & $37(100 \%)$ \\
c-Kit & $35(94.6 \%)$ \\
CD34 & $1(2.7 \%)$ \\
Desmin & $4(10.8 \%)$ \\
SMA & $2(5.4 \%)$ \\
S-100 & \\
No risk & $3(8.1 \%)$ \\
Very Low & $22(59.65 \%)$ \\
Low & $1(2.7 \%)$ \\
Moderate & $8(21.6 \%)$ \\
High & $3(8.1 \%)$ \\
Primary risk stratification & $4(10.8 \%)$ \\
Pocurrence, $n(\%)$ & $1(2.7 \%)$ \\
\hline
\end{tabular}

Values are presented as mean \pm standard deviation (range) or number (\%).

\subsection{Primary Pathologic Reports}

The most prominent histologic type was spindle-shaped $(n=33 ; 89.2 \%)$, followed by mixed epithelioid and spindle type $(n=4 ; 10.8 \%)$. The mitotic count was $\leq 5 / 50$ HPFs in 29 cases $(78.4 \%), 6-10 / 50$ HPF in 3 cases $(8.1 \%)$, and $>10 / \mathrm{HPF}$ in 5 cases (13.5\%). In the primary report, the original risk stratification by AFIP criteria suggested that 3 cases were at no risk, 22 were at very low risk, 1 was at low risk, 8 were at moderate risk, and 3 were at high risk (Table 2).

\subsection{Comparison of Risk Stratification between the Periphery and Center of Gastric GISTs}

Table 3 summarizes the EUS findings and risk stratification according to site of mitotic index analysis of the 37 cases included in this study. Among 37 gastric GISTs, $94.6 \%(n=35)$ showed the same level of risk stratification for the center and the periphery. Only two $(5.4 \%)$ cases had different risk stratification outcomes between the two sites. One case (case 9 in Table 3) was categorized as moderate risk in the original pathologic report but as very low risk and moderate risk according to assessment of the center and periphery of the gastric GIST, respectively. The other case (case 35) was categorized as moderate risk in the primary pathologic report but very low risk and moderate risk according to assessment of the center and periphery regions of the gastric GIST, respectively. Figure 3 showed the comparison of mitotic index between center and periphery site. Overall, mitotic index category $(>5 / \mathrm{HPF}, \leq 5 / \mathrm{HPF})$ of GISTs showed good agreement between the center and the periphery $(K=0.74 ; p<0.001)$. 
Table 3. Endoscopic ultrasound and pathological findings for total 37 cases.

\begin{tabular}{|c|c|c|c|c|c|c|c|c|c|c|c|c|c|c|c|}
\hline \multirow[b]{2}{*}{ Case } & \multirow[b]{2}{*}{ Gender } & \multicolumn{9}{|c|}{ EUS Findings } & \multicolumn{5}{|c|}{ Pathologic Findings } \\
\hline & & $\begin{array}{c}\text { Age } \\
\text { (range) }\end{array}$ & Location & Size $(\mathrm{cm})$ & Layer & Echogenecity & Heterogeneity & $\begin{array}{l}\text { Cystic } \\
\text { change }\end{array}$ & Size $(\mathrm{cm})$ & $\begin{array}{l}\text { Original } \\
(n / \mathrm{HPF})\end{array}$ & $\begin{array}{c}\text { Center } \\
(n / \mathrm{HPF})\end{array}$ & $\begin{array}{l}\text { Periphery } \\
(n / \mathrm{HPF})\end{array}$ & $\begin{array}{c}\text { Original } \\
\text { (risk) }\end{array}$ & $\begin{array}{l}\text { Center } \\
\text { (risk) }\end{array}$ & $\begin{array}{c}\text { Periphery } \\
\text { (risk) }\end{array}$ \\
\hline 1 & 1 & $60-70$ & Fundus & 4 & 4th & Нyро & Homo & Present & 3.5 & 104 & 46 & 120 & Moderate & Moderate & Moderate \\
\hline 2 & 2 & $50-60$ & Cardia & 3.6 & 4 th & Нуро & Hetero & Present & 5.3 & 8 & 10 & 15 & High & High & High \\
\hline 3 & 1 & $50-60$ & Antrum & 2.6 & 4 th & Нуро & Hetero & Present & 2.7 & 3 & 3 & 2 & Very low & Very low & Very low \\
\hline 4 & 2 & $50-60$ & Fundus & 3.1 & 4th & Нуро & Hetero & Present & 3.1 & 8 & 10 & 10 & Moderate & Moderate & Moderate \\
\hline 5 & 2 & $60-708$ & Fundus & 4.2 & 4th & Нуро & Hetero & Absent & 5.5 & 1 & 2 & 2 & Low & Low & Low \\
\hline 6 & 1 & $50-60$ & Body & 3.4 & 4th & Нуро & Hetero & Absent & 2.7 & 1 & 1 & 2 & Very low & Very low & Very low \\
\hline 7 & 1 & $60-70$ & Antrum & 2.4 & 4th & Нуро & Homo & Absent & 2.2 & 2 & 0 & 0 & Very low & Very low & Very low \\
\hline 8 & 2 & $60-70$ & Body & 2.2 & 4th & Нуро & Homo & Absent & 3 & 2 & 5 & 5 & Very low & Very low & Very low \\
\hline 9 & 1 & $50-60$ & Body & 3.2 & 4th & Нуро & Hetero & Absent & 3 & 7 & 4 & 7 & Moderate & Very low & Moderate \\
\hline 10 & 1 & $70-80$ & Fundus & 4.5 & 4 th & Нуро & Homo & Present & 4.5 & 2 & 4 & 2 & Very low & Very low & Very low \\
\hline 11 & 1 & $70-80$ & Body & 2.3 & 4 th & Нуро & Homo & Absent & 3 & 1 & 3 & 5 & Very low & Very low & Very low \\
\hline 12 & 2 & $60-70$ & Cardia & 2.4 & 4 th & Нуро & Homo & Present & 2.5 & 7 & 11 & 9 & Moderate & Moderate & Moderate \\
\hline 13 & 1 & $60-70$ & Antrum & 2.1 & 4th & Нуро & Hetero & Present & 2 & 3 & 3 & 4 & No risk & No risk & No risk \\
\hline 14 & 2 & $60-70$ & Fundus & 2.5 & $3 \mathrm{rd}$ & Нуро & Hetero & Absent & 2 & 0 & 2 & 1 & No risk & No risk & No risk \\
\hline 15 & 1 & $40-50$ & Cardia & 2.5 & 4 th & Нуро & Homo & Absent & 3 & 0 & 1 & 1 & Very low & Very low & Very low \\
\hline 16 & 2 & $60-70$ & Body & 2.7 & 4th & Нypo & Hetero & Absent & 3 & 5 & 3 & 3 & Very low & Very low & Very low \\
\hline 18 & 2 & $40-50$ & Body & 2.8 & 4 th & Нуро & Hetero & Absent & 3 & 3 & 2 & 1 & Very low & Very low & Very low \\
\hline 19 & 1 & $40-50$ & Body & 4.2 & 4 th & Нypo & Hetero & Absent & 4 & 2 & 1 & 2 & Very low & Very low & Very low \\
\hline 20 & 1 & $60-70$ & Fundus & 4.1 & 4 th & Нуро & Hetero & Absent & 5 & 50 & 30 & 27 & Moderate & Moderate & Moderate \\
\hline 21 & 1 & $50-60$ & Cardia & 4 & 4th & Нуро & Homo & Absent & 4 & 3 & 1 & 1 & Very low & Very low & Very low \\
\hline 22 & 2 & $60-70$ & Cardia & 3 & 4th & Нуро & Hetero & Present & 3.3 & 2 & 1 & 2 & Very low & Very low & Very low \\
\hline 23 & 2 & $50-60$ & Fundus & 2.5 & $3 r d$ & Нуро & Hetero & Absent & 2.7 & 3 & 2 & 1 & Very low & Very low & Very low \\
\hline 24 & 1 & $50-60$ & Body & 4 & 4th & Нуро & Homo & Absent & 3.5 & 1 & 3 & 0 & Very low & Very low & Very low \\
\hline 25 & 1 & $40-50$ & Cardia & 2.3 & 4th & Нуро & Hetero & Present & 2.2 & 2 & 0 & 0 & Very low & Very low & Very low \\
\hline 26 & 2 & $40-50$ & Cardia & 4.7 & 4 th & Нypo & Hetero & Present & 4.5 & 4 & 2 & 1 & Very low & Very low & Very low \\
\hline 27 & 2 & $70-80$ & Body & 2.2 & 4 th & Нуро & Homo & Absent & 2 & 1 & 2 & 2 & No risk & No risk & No risk \\
\hline 28 & 2 & $60-70$ & Body & 11 & 4 th & Нуро & Hetero & Present & 10.5 & 1 & 0 & 0 & Moderate & Moderate & Moderate \\
\hline 29 & 2 & $40-50$ & Cardia & 4.5 & 4 th & Нуро & Hetero & Present & 3.8 & 2 & 4 & 2 & Very low & Very low & Very low \\
\hline 30 & 2 & $50-60$ & Fundus & 11 & 4th & Нуро & Hetero & Present & 11.5 & 16 & 14 & 18 & High & High & High \\
\hline 31 & 2 & $50-60$ & Fundus & 3.5 & 4th & Hypo & Hetero & Absent & 2.3 & 0 & $\begin{array}{c}1 \mathrm{x} \\
0\end{array}$ & 0 & Very low & Very low & Very low \\
\hline 32 & 1 & $60-70$ & Fundus & 3 & 4th & Hypo & Hetero & Absent & 2.2 & 0 & 0 & 1 & Very low & Very low & Very low \\
\hline 33 & 1 & $70-80$ & Cardia & 2 & 4 th & Нyро & Hetero & Present & 2.1 & 7 & 16 & 11 & Moderate & Moderate & Moderate \\
\hline
\end{tabular}


Table 3. Cont.

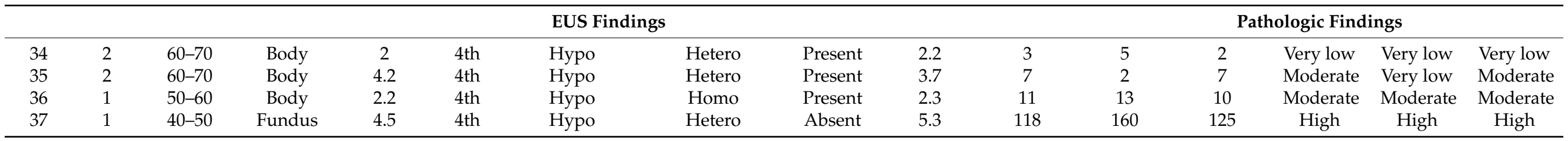




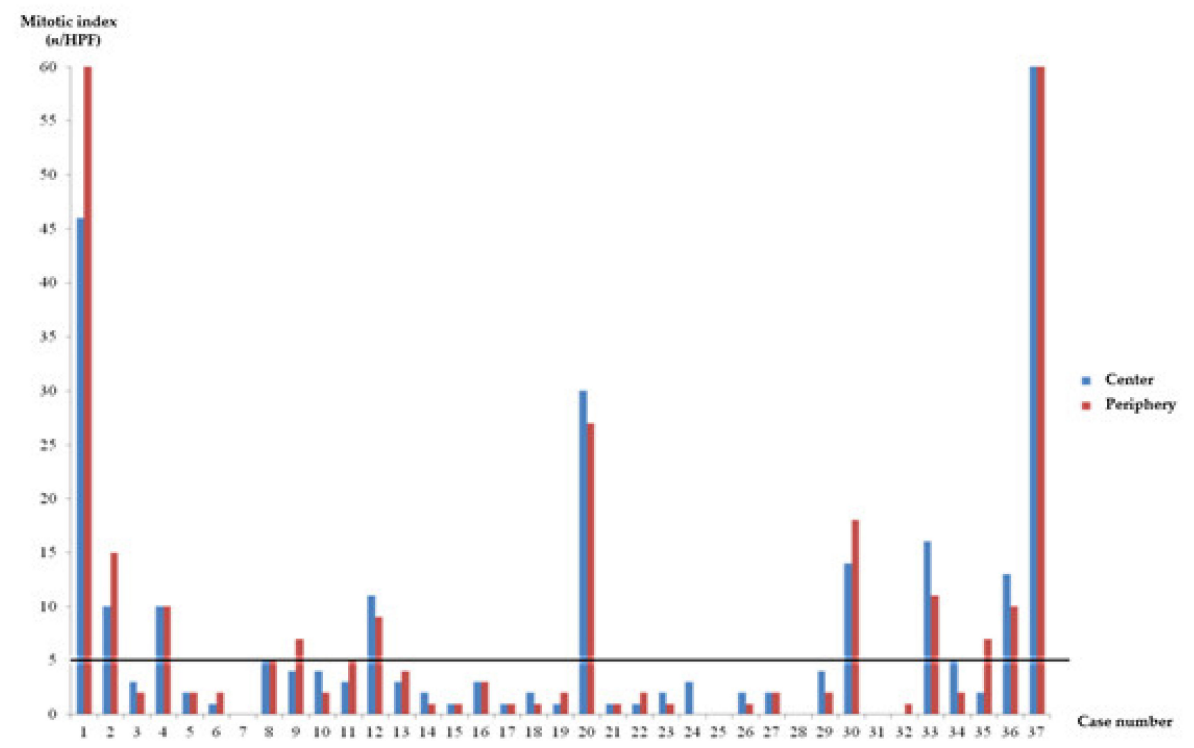

Figure 3. Mitotic index agreement between the center and the periphery. HPF, High-Power Field.

\section{Discussion}

In our study, mitotic indices of the periphery and center of gastric GISTs showed good concurrence. To the best of our knowledge, this study is the first to compare mitotic count between the center and periphery of gastric GISTs. Yasui et al. reported the heterogeneity of gastric GIST lesions using the MIB-1 index, and the discrepancy in the result might be due to the difference of the patient characteristics included: our study included only resectable gastric GISTs, but patients included in the study by Yasui et al. showed much larger mean diameter of GIST $(6.9 \pm 2.73$ vs. $3.56 \pm 2.10)$ [12]. This difference in result might suggests that the GIST could become more heterogenous as the size of the lesion increases or during the process of metastasis, but further research is needed. Usually gastric GISTs sized more than $2 \mathrm{~cm}$ are preferred to be removed [1]. However, if the patient had comorbidity or high risk of operation, accurate evaluation of risk classification is helpful to decide treatment plan. According to our results, since the heterogenicity of the central and peripheral is not significant, we think the biopsy at peripheral could assess risk classification.

GISTs are the most common mesenchymal tumors of the gastrointestinal tract and high incidence rates of 19 to 22 cases per one million inhabitants have been reported in Korea, China, and Norway [13]. While most GISTs are found in the stomach, 20\% to $30 \%$ are present in the small intestine, $5 \%$ to $15 \%$ present in the colon, and less than $5 \%$ present in the esophagus and other regions [8,14-16]. Although the only principal treatment of localized GISTs is surgical resection with negative margins, there is a risk for recurrence or metastasis; one cohort study reported that $29.4 \%$ of cases showed recurrence or metastasis following curative resection of gastric GISTs during a median 31.95 months of follow-up [17]. Our study revealed a lower recurrence rate of $2.7 \%$, which may be the result of bias due to our small sample size and inclusion of only patients with gastric GISTs who underwent curative surgical resection.

Contour maps based on a pooled population-based study of GISTs who received no adjuvant therapy revealed that tumor size, mitosis count, primary tumor site, and rupture can predict recurrence at 10 years after surgery [18]. Among these factors, high mitotic index is one important risk factor that has been included among various prognostic criteria for GISTs including the National Institutes of Health (NIH) classification, the modified $\mathrm{NIH}$ classification, and the AFIP classification $[7,9,10]$. In order to raise the survival rate in the resectable GIST tumor, for large tumor size and large mitotic count, tyrosine kinase inhibitors can be used as adjuvant therapy. Therefore, it is important to evaluate the mitotic count before treatment [19]. Usually, the number of mitoses is counted among 50 consecutive HPFs from the most cellularly dense areas (area of an individual field: $0.2 \mathrm{~mm} 2$ ); 
however, it is sometimes difficult to complete this because of subjectivity in relation to the pathologist or resection site involved. While preoperative histological diagnosis using EUS-guided FNA or deep biopsy is necessary to guide adjuvant therapy or patient counseling, EUS-guided biopsy presents the limitation of small tissue volume. In our study, only $5.4 \%$ of cases showed different risk categories for the center and peripheral sites, and there was good concurrence of mitotic count on the basis of 5/HPF between the center and periphery. Surprisingly, the original data largely matched in terms of risk category with the periphery but the not center results, suggesting that peripheral small-tissue sampling through EUS-guided FNA or deep biopsy may be enough to assess mitosis among patients with gastric GISTs. Our study had several limitations. First, this study had a retrospective design and a small number of patients. Second, we did not analyze the pathologic results using EUS-guided FNA or deep biopsy because preoperative biopsy tends not to be performed when GISTs are strongly suspected and surgery is under consideration. Third, our study only included gastric GIST that is usually rather low risk of malignancy. Therefore, our finding may be difficult to apply to other tumors such as high risk tumors, or other sites of GIST lesions.

\section{Conclusions}

Our data indicated that mitotic indices of the periphery and center of gastric GISTs showed good concurrence, and the periphery was the same risk category as the original data. Biopsy using endoscopic approaches is likely to represent whole gastric GIST mass, although there is some degree of limitation because of the limited tissue volume and difficulty with approaching the tumor.

Author Contributions: Conceptualization: S.J.C., K.H.L., and H.L.L.; methodology: S.J.C. and H.L.L.; formal analysis: Y.J.K., C.K.Y., K.S.J., and J.H.Y.; data curation: S.J.C. and K.H.L.; investigation: K.S.J.; writing-original draft preparation: S.J.C., K.H.L., and Y.J.K.; writing-review and editing: C.K.Y., K.S.J., J.H.Y., and H.L.L.; visualization: S.J.C. and K.H.L., supervision: Y.J.K. and H.L.L.; project administration: H.L.L.; funding acquisition: H.L.L. All authors have read and agreed to the published version of the manuscript.

Funding: This work was supported by the research fund of Hanyang University (HY-2015). The funders did not have a role in the design or conduct of the study but did provide financial support for statistical consultation and English editing.

Institutional Review Board Statement: The study was conducted according to the guidelines of the Declaration of Helsinki, and approved by the Institutional Review Board of Hanyang University Seoul Hospital (no. 2015-02-004-001).

Informed Consent Statement: Patient consent was waived for the retrospective analysis.

Data Availability Statement: The datasets used and/or analyzed are available from the corresponding author on reasonable request. The data are not publicly available due to ethical and privacy restrictions.

Conflicts of Interest: All authors declare no conflict of interest.

\section{References}

1. El-Menyar, A.; Mekkodathil, A.; Al-Thani, H. Diagnosis and management of gastrointestinal stromal tumors: An up-to-date literature review. J. Cancer Res. Ther. 2017, 13, 889. [PubMed]

2. Nomura, E.; Ioka, A.; Tsukuma, H. Incidence of soft tissue sarcoma focusing on gastrointestinal stromal sarcoma in Osaka, Japan, during 1978-2007. Jpn. J. Clin. Oncol. 2013, 43, 841-845. [CrossRef] [PubMed]

3. Perez, E.A.; Livingstone, A.S.; Franceschi, D.; Rocha-Lima, C.; Lee, D.J.; Hodgson, N.; Jorda, M.; Koniaris, L.G. Current incidence and outcomes of gastrointestinal mesenchymal tumors including gastrointestinal stromal tumors. J. Am. Coll. Surg. 2006, 202, 623-629. [CrossRef]

4. Chiang, N.-J.; Chen, L.-T.; Tsai, C.-R.; Chang, J.S. The epidemiology of gastrointestinal stromal tumors in Taiwan, 1998-2008: A nation-wide cancer registry-based study. BMC Cancer 2014, 14, 102. [CrossRef] [PubMed]

5. Parab, T.M.; DeRogatis, M.J.; Boaz, A.M.; Grasso, S.A.; Issack, P.S.; Duarte, D.A.; Urayeneza, O.; Vahdat, S.; Qiao, J.-H.; Hinika, G.S. Gastrointestinal stromal tumors: A comprehensive review. J. Gastrointest. Oncol. 2019, 10, 144. [CrossRef] [PubMed] 
6. Khoo, C.Y.; Chai, X.; Richard, Q.; Teo, M.C.; Goh, B.K. Systematic review of current prognostication systems for primary gastrointestinal stromal tumors. Eur. J. Surg. Oncol. 2018, 44, 388-394. [CrossRef] [PubMed]

7. Joensuu, H. Risk stratification of patients diagnosed with gastrointestinal stromal tumor. Hum. Pathol. 2008, 39, 1411-1419. [CrossRef]

8. Miettinen, M.; Sobin, L.H.; Lasota, J. Gastrointestinal stromal tumors of the stomach: A clinicopathologic, immunohistochemical, and molecular genetic study of 1765 cases with long-term follow-up. Am. J. Surg. Pathol. 2005, 29, 52-68. [CrossRef] [PubMed]

9. Fletcher, C.D.; Berman, J.J.; Corless, C.; Gorstein, F.; Lasota, J.; Longley, B.J.; Miettinen, M.; O’Leary, T.J.; Remotti, H.; Rubin, B.P. Diagnosis of gastrointestinal stromal tumors: A consensus approach. Int. J. Surg. Pathol. 2002, 10, 81-89. [CrossRef] [PubMed]

10. Miettinen, M.; Lasota, J. Gastrointestinal stromal tumors: Pathology and prognosis at different sites. Semin. Diagn. Pathol. 2006, 23, 70-83. [CrossRef] [PubMed]

11. DeMatteo, R.P.; Gold, J.S.; Saran, L.; Gönen, M.; Liau, K.H.; Maki, R.G.; Singer, S.; Besmer, P.; Brennan, M.F.; Antonescu, C.R. Tumor mitotic rate, size, and location independently predict recurrence after resection of primary gastrointestinal stromal tumor (GIST). Cancer Interdiscip. Int. J. Am. Cancer Soc. 2008, 112, 608-615. [CrossRef] [PubMed]

12. Yasui, H.; Konishi, E.; Urasaki, K.; Yasukawa, S.; Yanagisawa, A. Intratumoral heterogeneity of MIB-1 labelling index in gastric gastrointestinal stromal tumor (GIST). Gastric Cancer 2006, 9, 223-228. [CrossRef] [PubMed]

13. Søreide, K.; Sandvik, O.M.; Søreide, J.A.; Giljaca, V.; Jureckova, A.; Bulusu, V.R. Global epidemiology of gastrointestinal stromal tumours (GIST): A systematic review of population-based cohort studies. Cancer Epidemiol. 2016, 40, 39-46. [CrossRef] [PubMed]

14. Wardelmann, E.; Hohenberger, P.; Reichardt, P.; Merkelbach-Bruse, S.; Schildhaus, H.U.; Büttner, R. Gastrointestinale Stromatumoren des Magens. Der Pathol. 2010, 31, 195-198. [CrossRef] [PubMed]

15. Tran, T.; Davila, J.A.; El-Serag, H.B. The epidemiology of malignant gastrointestinal stromal tumors: An analysis of 1458 cases from 1992 to 2000. Am. J. Gastroenterol. 2005, 100, 162-168. [CrossRef] [PubMed]

16. Nilsson, B.; Bümming, P.; Meis-Kindblom, J.M.; Odén, A.; Dortok, A.; Gustavsson, B.; Sablinska, K.; Kindblom, L.G. Gastrointestinal stromal tumors: The incidence, prevalence, clinical course, and prognostication in the preimatinib mesylate era: A population-based study in western Sweden. Cancer 2005, 103, 821-829. [CrossRef] [PubMed]

17. Supsamutchai, C.; Wilasrusmee, C.; Hiranyatheb, P.; Jirasiritham, J.; Rakchob, T.; Choikrua, P. A cohort study of prognostic factors associated with recurrence or metastasis of gastrointestinal stromal tumor (GIST) of stomach. Ann. Med. Surg. 2018, 35, 1-5. [CrossRef] [PubMed]

18. Joensuu, H.; Vehtari, A.; Riihimäki, J.; Nishida, T.; Steigen, S.E.; Brabec, P.; Plank, L.; Nilsson, B.; Cirilli, C.; Braconi, C. Risk of recurrence of gastrointestinal stromal tumour after surgery: An analysis of pooled population-based cohorts. Lancet Oncol. 2012, 13, 265-274. [CrossRef]

19. Ishikawa, T.; Kanda, T.; Kameyama, H.; Wakai, T. Neoadjuvant therapy for gastrointestinal stromal tumor. Transl. Gastroenterol. Hepatol. 2018, 3, 3. [CrossRef] [PubMed] 